\title{
BMA threatens legal action over coroner's advice over death verification
}

\section{Gareth lacobucci}

The BMJ

The BMA has threatened the chief coroner of the county of Essex with legal action unless guidance for local GPs-which states that only healthcare workers could verify deaths in the region-is withdrawn.

In April, as the covid-19 pandemic escalated, Essex senior coroner Caroline Beasley-Murray wrote to local GPs instructing them that it was only acceptable for healthcare workers to verify expected deaths, and that this must be done in person.

But in a letter to the coroner, BMA lawyers said that the direction is contrary to English law, which states that any competent adult can verify a death. They also noted that it was not supported by joint guidance from the BMA and the Royal College of General Practitioners, ${ }^{1}$ or separate guidance from NHS England NHS Improvement. ${ }^{2}$

Demanding that healthcare workers attend to verify deaths unnecessarily diverts staff from direct patient care at a time when they are most needed and puts both staff and others at risk by potentially exposing them to covid-19, the BMA said.

The BMA's letter also states that the coroner has no legal jurisdiction over verification of death or the confirmation that someone has died. It said that this is separate to the process of death certification, which records the cause of death.

It said this was recently supported by the Ministry of Justice, which confirmed that coroners have "no legal powers, authority, or mandate concerning the verification of death."

The BMA-with the support of Essex Local Medical Committee-has requested that the Essex chief coroner clarifies the legal basis for their direction. If a suitable response isn't received in good time, the BMA said it will consider legal action in the form of a judicial review.
Mark Sanford-Wood, deputy chair of the BMA's GP committee, said, "For years, GPs and their local coroners have worked together to ensure a sensible and sensitive approach to certifying deaths. Therefore, it's incredibly disappointing to see coroners during this pandemic taking it upon themselves to put themselves ahead of the law, making unrealistic and unsafe demands."

Victoria Tzortziou-Brown, joint honorary secretary of the Royal College of General Practitioners, which is named as an interested party in the letter, said, "In these extraordinary times, there is a need for various groups to work differently and together as one system. This is why, in collaboration with the BMA, we have produced guidance for the verification of expected death with the remote assistance of other workers, ensuring that bereaved families do not experience needless delays, reducing the risk of unnecessary exposure to the virus, and allowing clinicians to continue on the front line."

Addendum: Since this story was published The BMJ has learnt that the senior coroner (not "chief coroner" as originally stated) for Essex has updated the guidance in line with the Department of Health and Social Care's advice published on 5 May.

BMA. Covid-19: death certification and cremation. www.bma.org.uk/advice-and-support/ covid-19/adapting-to-covid/covid-19-death-certification-and-cremation.

2 NHS England NHS Improvement. Death verification (confirmation of death) of expected deaths during the covid-19 pandemic. 12 April 2020. www.serjeantsinn.com/wp-content uploads/2020/04/Guidance-on-verification-of-expected-death-approved-by-LCAG-12thApril-2....pdf.

Published by the BMJ Publishing Group Limited. For permission to use (where not already granted under a licence) please go to http://group.bmj.com/group/rights-licensing/ permissions 